УДК 340.0 (477):343.82

DOI https://doi.org/10.32837/pyuv.v0i2(23).923

М. М. Гультай

orcid.org/0000-0001-7773-0501

доктор юридичних наук, доцент, професор кафедри конституиійного права та прав людини Національної акаделії внутрішніх справ

А. О. Осауленко orcid.org/0000-0003-3125-1892

доктор юридичних наук, доцент, доцент кафедри конституиійного права та прав людини Національної акаделії внутрішніх справ

\title{
КРИМІНАЛЬНО-ВИКОНАВЧІ КОДЕКСИ УКРАЇНИ ТА РЕСПУБЛІКИ БІЛОРУСЬ: ПОРІВНЯЛЬНО-ПРАВОВИЙ АСПЕКТ
}

Постановка проблеми. У сучасних умовах світовий правовий розвиток характеризується активним взаємовпливом складових елементів національних правових систем, особливо в межах одного типу права. Як показує практика правового регулювання суспільних відносин, такі процеси значною мірою сприяють правовому прогресу.

Як справедливо зазначає М. Ансель, процес порівняння національних правових систем та їх складових елементів відкриває перед юристами багато нових можливостей для кращого розуміння права своєї країни. Саме порівняння дає змогу озброїти юриста новими ідеями, які неможливо отримати, навіть дуже добре знаючи і розуміючи вітчизняне право та законодавство [1, с. 38].

У зв'язку з вищезазначеним порівняльний аналіз змісту КВК України з кримінально-виконавчим законодавством зарубіжних країн, зокрема й з КВК Республіки Білорусь, має важливе як наукове, так і практично-прикладне значення, особливо в контексті здійснення реформи пенітенціарної системи України.

Аналіз останніх досліджень. До прийняття у 2003 р. КВК України порівняльні дослідження у сфері виконання кримінальних покарань не привертали особливої уваги з боку вчених-пенітенціаристів нашої держави. Цей факт, на нашу думку, відіграв певну негативну роль у процесі формування змісту зазначеного кодексу. I лише через більш як 5 років після прийняття КВК України в нашій державі розпочались досить активні порівняльні дослідження у сфері виконання кримінальних покарань. Саме цим питанням останнім часом присвятили свої праці I. Богатирьов, О. Богатирьова, Т. Денисова, Д. Казначеєва, О. Колб, І. Копотун, А. Морозов, Н. Панасюк, М. Пузирьов, А. Степанюк, О. Шкута, Д. Ягунов, I. Яковець, М. Яцишин та інші.

Вищезазначеними авторами порівняльно-правові дослідження у сфері виконання покарань здійснювались переважно щодо західних держав, залишаючи поза увагою зміст кримінально-виконавчого законодавства пострадянських держав, що, на нашу думку, є не зовсім правильним, оскільки саме вони є найбільш близькими до України не тільки за правовими витоками, але й історичними та національними традиціями, менталітетом тощо.

Метою статті є дослідження спільних та відмінних рис кримінально-виконавчих кодексів України та Республіки Білорусь для вдосконалення процесу адаптації вітчизняного пенітенціарного законодавства до європейських і світових стандартів.

Виклад основного матеріалу. Характеризуючи Кримінально-виконавчі кодекси України та Республіки Білорусь, варто підкреслити, що, перебуваючи у складі СРСР, виправно-трудові, а потім кримінально-виконавчі законодавства окремих союзних республік, зокрема кримінально-виконавчі кодекси (в той час виправно-трудові), за своєю структурою і змістом мало чим відрізнялись між собою [2, с. $13 ; 3$, с. 391].

Як в Україні, так і в Республіці Білорусь ще до прийняття КВК у місцях позбавлення волі було відмінено багато правообмежень карального характеру та активізувалась робота представників різноманітних громадських та релігійних організацій, а також засобів масової інформації.

Водночас варто зазначити, що пострадянське минуле та його традиції постійно здійснювали і дотепер здійснюють вплив на зміст та структуру всіх галузей національного законодавства пострадянських держав. Не є винятком і зміст та структура Кримінально-виконавчих кодексів як України [4], так і Республіки Білорусь [5], які за своєю структурою є близькими до раніше чинних виправно-трудових кодексів цих союзних республік, тобто структура кодексів фактично є ідентичною, хоча їх зміст досить суттєво 
відрізняється один від одного [3, с. 391]. Видається, на різний зміст досліджуваних кодексів також суттєво вплинув і час їх прийняття.

Характеризуючи будь-який законодавчий, тим більше кодифікований, акт, важливо визначити його цілі та завдання. Такі цілі і завдання закріплені в ст. 1 КВК України та в ст. 2 КВК Республіки Білорусь, хоча їх зміст досить суттево відрізняється один від одного.

Позитивним моментом у тексті кодексів України та Республіки Білорусь є те, що в них закріплені принципи кримінально-виконавчого законодавства, яким присвячена в кожному 3 кодексів окрема стаття. Перелік та зміст зазначених принципів у кожному з кодексів значною мірою збігаються, хоча водночас мають особливості.

Загальним недоліком обох кодексів, на нашу думку, $є$ те, що зміст вищезгаданих принципів законодавцями обох країн не розкривається. Видається, цей недолік зумовлений багатоманіттям наукових підходів до сутності та змісту принципів, що свідчить про те, що в науках кримінальновиконавчого права як України, так і Білорусі відсутній єдиний підхід до розуміння принципів кримінально-виконавчого права [3, с. 392].

Важливо зазначити, що у КВК України та Республіки Білорусь звернуто увагу на виправлення засуджених. Водночас законодавці кожної держави по-різному формулюють нормативне визначення цього поняття.

Зокрема, за ч. 2 ст. 7 КВК Республіки Білорусь виправлення засуджених - це формування у них готовності вести правослухняний спосіб життя. Відповідно ж до ч. 1 ст. 6 КВК України виправлення засудженого являє собою процес позитивних змін, які відбуваються в його особистості та створюють у нього готовність до самокерованої правослухняної поведінки.

У ч. 2 ст. 6 КВК України КВК України закріплений термін "ресоціалізація засуджених» як свідоме відновлення засудженого в соціальному статусі повноправного члена суспільства; повернення його до самостійного загальноприйнятого соціально-нормативного життя в суспільстві. У КВК ж Республіки Білорусь цей термін не зустрічається взагалі.

Закріпивши в кодексах виправлення засуджених, законодавці досліджуваних держав окремою статтею визначили основні засоби його досягнення, які за своїм змістом практично збігаються.

Позитивним у змісті кодексів як України, так і Республіки Білорусь $є$ і те, що в них досить чітко закріплено основи правового статусу засуджених. Цьому питанню в кожному з кодексів присвячено окрему главу.

У КВК Білорусі обов'язки засуджених поставлені на перше місце, що свідчить про відчутний вплив радянських правових традицій, коли обов'язки громадянина висувались на перше місце, тоді як їхні права часто розглядались лише в другу чергу.

Видається, що на зміст і структуру КВК України значно більший вплив здійснила європейська правова традиція функціонування пенітенціарних систем, а тому в його тексті, як і в більшості західноєвропейських держав, права засуджених поставлені на перше місце, а вже потім регламентовані їхні обов'язки.

Виправні колонії в Білорусі поділяються на колонії-поселення, виправні колонії для осіб, які вперше відбувають покарання у виді позбавлення волі, виправні колонії для осіб, які раніше відбували покарання у виді позбавлення волі, виправні колонії особливого режиму (ст. 64 КВК Республіки Білорусь). Таким чином, КВК Білорусі фактично зберіг структуру та функції виправно-трудових установ радянського періоду. Зміни зазнала лише назва, де замість «виправно-трудових установ» 3 'явились «виправні установи».

В Україні кримінально-виконавчі установи отримали сучасну назву, яка в більшій мірі відповідає як європейській, так і світовій традиціям пенітенціарних систем. До того ж вітчизняне пенітенціарне законодавство наділило особливим правовим статусом виховні колонії для неповнолітніх.

У законодавстві України, на відміну від Республіки Білорусь, виправні установи з назвою «колонії-поселення» не передбачені. Натомість у ст. 16 КВК України запропоновані установи відкритого типу - виправні центри.

Необхідно зазначити, що їх правовий статус за своїм змістом та умовами відбування покарань $\epsilon$ близьким до статусу колоній-поселень. Такі установи розташовані, як правило, поруч із невеликими населеними пунктами України.

Розглядаючи законодавче регулювання та практику виконання всіх видів кримінальних покарань із позиції гуманізму, варто зазначити, що їх сутність в Україні та Білорусі практично не відрізняється. Винятком є лише законодавче регулювання виконання покарань у виді позбавлення волі. Видається, що одним із найбільш важливих критеріїв є застосування до осіб, позбавлених волі, дисциплінарних стягнень. Незважаючи на те, що принцип гуманізму закріплений у КВК Республіки Білорусь, у цій країні серед заходів стягнення, які застосовуються до засуджених до позбавлення волі, мають місце й позбавлення права на отримання чергової посилки чи передачі, а також позбавлення чергового тривалого чи короткострокового побачення (ст. 112 КВК Республіки Білорусь).

Висновки. В Україні та в Республіці Білорусь у процес реформування національного кримінально-виконавчого законодавства були 
закладені загальні підходи та принципи. Вони базувались на загальновизнаних міжнародних актах та були спрямовані на загальну гуманізацію умов відбування покарань. У процесі реформування пенітенціарних систем у місцях позбавлення волі обох країн були скасовані значні обмеження карального характеру.

Кримінально-виконавчий кодекс Республіки Білорусь був прийнятий майже на чотири роки раніше, що зумовило прийняття відповідного вітчизняного кодексу з урахуванням як позитивного, так і негативного досвіду практичного застосування положень основного кодифікованого акта в Білорусі.

Обидва кодекси на нормативному рівні закріпили основи правового статусу засуджених. Водночас в Україні така регламентація більшою мірою здійснена з урахуванням європейської правової традиції функціонування пенітенціарних систем.

\section{Jimepamypa}

1. Ансель М. Методологические проблемы сравнительного права. Очерки сравнительного права : сборник. Москва : Прогресс, 1981. С. 36-86.

2. Осауленко А. Пенитенциарное законодательство Украины и Республики Молдова: сравнительно-правовой аспект. Jurnalul Juridic National: Teorie si Practica. 2017. № 1 (23). C. 13-17.

3. Осауленко А.О. Пенитенциарное законодательство Украины и Республики Беларусь: сравнительно-правовой аспект. Актуальные вопросы совре менной юридической науки: теория, практика, методика : сборник материалов II Международной заочной научной конференции, г. Могилев, 19 мая 2017 г. Могилев, 2017. С. 391-393.

4. Кримінально-виконавчий кодекс України : Закон України від 11.07.2003 р. № 1129-IV. Дата оновлення: 14.07.2021 / Верховна Рада України. URL: https://zakon.rada.gov.ua/laws/show/1129-15 (дата звернення: 25.11.2021).

5. Уголовно-исполнительный кодекс Республики Беларусь от 11.01.2000 г. URL: https://kodeksy-by.com/ ui_kodeks_rb.htm\#google_vignette_(дата звернення: 25.11.202 $\overline{1}$ ).

\section{Анотація}

Гультай М. М., Осауленко А. О. Кримінальновиконавчі кодекси України та Республіки Білорусь: порівняльно-правовий аспект. - Стаття.

У статті досліджено спільні та відмінні риси кримінально-виконавчих кодексів України та Республіки Білорусь як основних кодифікованих нормативно-правових актів пенітенціарних систем обох країн.

Здійснено порівняльно-правовий аналіз динаміки розвитку відповідних кодексів з урахуванням пострадянського минулого, а також положень, що сформульовані в загальновизнаних міжнародних актах.

Наголошується на тому, що в колишньому Радянському Союзі виправно-трудові законодавства окремих союзних республік, зокрема виправно-трудові кодекси, за своєю структурою і змістом мало відрізнялись.

Звернуто увагу на те, що після проголошення незалежності в Україні та Республіці Білорусь розпочалися процеси скасування значної кількості правообмежень карального характеру та поступової гуманізації вико- нання кримінальних покарань загалом, а також покарань у виді позбавлення волі зокрема.

Активна діяльність представників різноманітних громадських та релігійних організацій, а також засобів масової інформації сприяла якнайкращому втіленню принципів кримінально-виконавчого законодавства, яким у кримінально-виконавчих кодексах України та Республіки Білорусь присвячено окремі статті.

Наголошено, що відсутність єдиного доктринального підходу до розуміння принципів кримінальновиконавчого права призвела до того, що зміст відповідних принципів у текстах кримінально-виконавчих кодексів України та Республіки Білорусь не розкрито.

Як позитивний момент зазначено, що в Кримінально-виконавчих кодексах України та Республіки Білорусь виправлення засуджених визначено як одне із завдань кримінально-виконавчого законодавства. Водночас законодавці кожної з держав по-різному формулюють нормативне визначення цього поняття.

Ключові слова: нормативно-правовий акт, пенітенціарне законодавство, Кримінально-виконавчий кодекс, гуманізація виконання кримінальних покарань, принципи кримінально-виконавчого законодавства.

\section{Summary}

Hultai M. M., Osaulenko A. O. Criminal executive codes of Ukraine and the Republic of Belarus: comparative and legal aspect. - Article.

The article examines the common and distinctive features of the criminal executive codes of Ukraine and the Republic of Belarus as the main codified legal acts of the penitentiary systems of both countries.

Comparative legal analysis of the dynamics of the development of the relevant codes, taking into account the post-Soviet past, as well as the provisions formulated in generally accepted international instruments was conducted.

It is emphasized that in the former Soviet Union the correctional labor legislation of individual union republics, in particular the correctional labor codes, differed little in terms of structure and content.

Attention is drawn to the fact that after declaration of independence in Ukraine and the Republic of Belarus, processes were started for abolishing the significant number of criminal restrictions and gradual humanization of criminal punishment in general, as well as imprisonment in particular.

The active work of representatives of various public and religious organizations, as well as the media contributed to the best implementation of the principles of criminal executive legislation, which are covered by certain articles in the criminal executive codes of Ukraine and the Republic of Belarus.

It is emphasized that the lack of a unified doctrinal approach to understanding the principles of criminal executive law have led to the fact that the content of the relevant principles in the texts of the criminal executive codes of Ukraine and the Republic of Belarus is not covered.

As a positive point it is noted that the Criminal Executive Codes of Ukraine and the Republic of Belarus define the correction of convicts as one of the tasks of criminal executive legislation. At the same time, the legislators of each state formulate the normative definition of this concept differently.

Key words: legal act, penitentiary legislation, criminal-executive code, humanization of execution of criminal punishments, principles of criminal-executive legislation. 